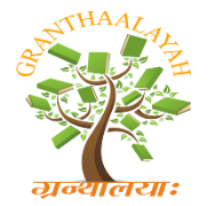

\author{
INTERNATIONAL JOURNAL OF RESEARCH - \\ GRANTHAALAYAH \\ A knowledge Repository
}

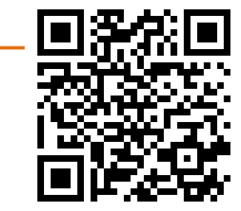

Management

\title{
TAX INCENTIVES AND INDUSTRIAL DEVELOPMENT IN BANGLADESH: AN EVALUATION OF POLICY IMPACT ON SECTORAL GROWTH
}

\author{
Mohammad Munayem Chowdhury ${ }^{* 1}$ \\ ${ }^{* 1} \mathrm{PhD}$ Researcher Institute of Bangladesh Studies (IBS), University of Rajshahi, Bangladesh
}

\begin{abstract}
Tax incentives are tools used worldwide to enhance domestic and foreign investment and enhanced investment leads to expected economic growth. This study is an attempt to review the industrial policies and direct tax incentives of Bangladesh to have a deep insight on the congruence among them and also show some indirect impact of tax incentives on development through analyzing some fiscal and investment data. Content and document analysis method has been used to accomplish this study. Sources of data were the industrial policies, tax codes and economic surveys of Bangladesh and some scholarly articles. By reviewing some tax related aspects of industrial polices and existing direct tax incentives provided by the tax authority, it was found that incentives suggested by industrial policies and actually provided tax incentives are almost same and the changing pattern of priority sectors have been shifted to infrastructure, power and technology sectors. By observing some investment and GDP related data it is found that local private sector investments are dominant over FDI and the manufacturing sectors contribution to GDP are increasing and consistent in last 13 years.
\end{abstract}

Keywords: Tax Incentives; Industrial Policy; Local Investment; Economic Development.

Cite This Article: Mohammad Munayem Chowdhury. (2019). "TAX INCENTIVES AND INDUSTRIAL DEVELOPMENT IN BANGLADESH: AN EVALUATION OF POLICY IMPACT ON SECTORAL GROWTH." International Journal of Research - Granthaalayah, 7(7), 321-330. https://doi.org/10.29121/granthaalayah.v7.i7.2019.770.

\section{Introduction}

Policies are important guideline to help develop any country. Of them tax policies and industrial policies are vital for sustainable industrial development. Through these policies different tax incentives are provided for expected industrial development and industrial development leads to national development through additional contribution to GDP. In this way tax incentives and industrial development are related to some extent. In the developing countries tax incentives are provided to attract both local and foreign direct investment (FDI), nurture infant industries and to correct externalities. The tools of choice are often tax holidays, accelerated depreciations, special economic zones, and reinvestment incentives. There are so many studies on incentives and FDI 
relation covering developed and developing countries and the result was mixed for different economic realities. But there is hardly any study on incentives and local investment relation. In this study National Industrial Policy (NIP) 2005, 2010 and 2016 of Bangladesh and different tax incentives provided under direct taxation of that period have been reviewed to see some points of congruence among them and the impact of those incentives to investment and development are examined by observing some fiscal and investment data.

\section{Literature Review}

A lot of studies have been conducted regarding tax incentives and FDI relation but in the field of local investment there is a few studies available and hardly any study in relation to Bangladesh. In Bangladesh tax incentives are provided indiscriminately both for foreign and local investment. Some of the articles regarding tax incentives and industrial development are presented below:

A study has been conducted on the effectiveness of the South Africa's tax incentives in generating additional manufacturing investment (Barbour, 2005). In that study some qualitative and quantitative data have been reviewed and the result has supported the hypothesis that the impact of tax incentives on manufacturing investment has been negligible. This paper concluded with some recommendations for the way forward, especially to rationalize the number of incentives and to move away from the use of discretionary allocation systems.

A study was conducted on the effect of establishing Special Economic Zones (SEZ) on economic development of China (Alder, Shao, \& Zilibotti, 2013) by using data from a panel of 276 Chinese cities and prefectures from 1988 to 2010 and they found that the establishment of a state-level SEZs were associated with an increase in the level of GDP of about $20 \%$.

A study conducted on the impact of tax incentives on industrial growth of Sub-Sahara African States (Siyanbola, Adedeji, Festus, \& Rahman, 2017) indicated positive effect of tax incentives on industrial and economic growth and also suggested that increasing tax incentives to productive and priority sectors of African economy has increased the continent's GDP.

A study has been conducted on the effectiveness of industrial policies exploiting geographic and sectoral variation (Gebrewolde \& Rockey, 2016). They had used product-level data on Ethiopian manufacturing firms and showed that the policy was unsuccessful. There was no improvement in productivity, productive assets, or employment.

A study has been conducted on incentives and revenue productivity of the Nigerian tax system from 1981 to 2009 periods to identify the short-run performance of various taxes (Oriakhi \& Osemwengie, 2013). The study indicated unsatisfactory level of total tax revenue productivity in Nigeria and they have mentioned some causes for that negative association like- institutional failing, corruption in the tax system and the negligence created by the management of both oil and non-oil revenue.

A study was conducted on tax incentives and investment to review both theoretical and empirical literatures to establish the merits and demerits of tax incentives (Munongo, Akanbi, \& Robinson, 2017).They found that, most of the empirical studies have been explored are concluded that though 
tax incentives might be important in attracting FDI they are more effective when combined with other non-tax factors.

A study was conducted on corporate tax incentives and its purposes and has explained the tradeoff between revenue losses and how to maintain an attractive corporate tax environment in a world of high tax competition. (The institute of fiscal studies, 2018).

A study was conducted to analyze the effects of the use of tax incentives on foreign direct investment performance in the Middle East and North Africa (MENA) region, based on a review of international best practice and some empirical evidence. It found that, generally best practices discourage the use of special tax incentives to attract FDI and have suggested a reduced statutory corporate income tax rate on a broad tax base (OECD, 2007).

A study was conducted on the effects of tax incentives by considering two empirical questions about tax incentives: (i) are incentives used as tools of tax competition and (ii) how effective are incentives in attracting investment? (Klemm \& Parys, 2012). To answer these, they prepared a panel dataset and found evidence that lower CIT rates and longer tax holidays are effective in attracting FDI in Latin America and the Caribbean but not in Africa.

A study was conducted on FDI in Bangladesh (Abdin, 2015) by using some investment figure and have shown the trend of FDI flow in Bangladesh after the trade liberalization in 1991 and onwards. It showed that FDI flow was consistently increasing in the beginning but in recent years it is stagnant. This paper also find out some challenges and make some recommendation in this regard. A study was conducted on the impact of Foreign Direct Investment (FDI) on the sectoral (agriculture, industry and service) growth pattern of Bangladesh economy. This study dealt with data from secondary sources and estimated the relationship based on Pearson Correlation Coefficient and revealed that FDI inflow in the industrial sector did not appear to correlate much with industrial growth, however, it relates better with service sector growth (Robin, 2006).

A study was conducted on the effects of FDI on domestic firms of some Central and Eastern European countries (Konings, 2001) and showed some negative spill over like — it crowds out and take away market opportunities from domestic enterprises and make the domestic firms less efficient.

In a recent study conducted on shared supplier's spill overs of FDI on Bangladeshi garments firms to highlight that local intermediate inputs might enhance domestic firms' performance, through the shared supplier spillovers of foreign direct investment (FDI) firms. It found that, the shared supplier spillovers of FDI has explained 1/4 of the product scope expansion and 1/3 of the productivity gains within domestic firms (Kee, 2015).

\section{Objectives}

- to review the industrial policies and direct tax incentives of Bangladesh to identify some points of congruence between them; and

- to show the impact of direct tax incentives on the local private sector investment specially on the manufacturing sector. 


\section{Materials and Methods}

The study is exploratory in nature. Content and document analysis methods are used to accomplish this study. To achieve the stated objectives the researcher has reviewed the National Industrial Policies 2005, 2010 and 2016 of Bangladesh and also reviewed the tax incentives provided under the Income Tax Ordinance (ITO) 1984 of Bangladesh of that time to see the congruence between them. And to achieve the second objective the researcher has collected and analyzed some fiscal and investment data to show the growth trend of those sectors. Sources of data are National Industrial Policies (NIP), tax code, finance acts, S.R.O.s and circulars issued by tax authority, budget speech, and economic review of Bangladesh, website of Ministry of Finance, NBR and BIDA. Some scholarly articles on tax incentives and industrial development are also reviewed for this purpose.

\section{Industrial Policies and Tax Incentives: Seeking Congruence}

One may think that industrial policy suggested priority sectors, tax incentives and tax incentives provided by the tax authority to the industry sectors will be congruent in many aspect if there is coordination among the govt. agencies. To justify this common sense observation, the researcher has reviewed the industrial policy 2005, 2010 and 2016 by considering policy objectives, suggested direct tax incentives and priority sectors to know the shifting pattern of priorities over time. And in the tax incentives part the researcher have reviewed the direct tax incentives available to the manufacturing sector of Bangladesh, their category and the trend and pattern of direct tax incentives provided under ITO 1984. In this section the researcher will seek congruence between industrial policies and tax incentives in the field of priority sectors and direct tax incentives by reviewing the above mentioned aspects.

\subsection{Congruence in Priority Sectors}

\subsubsection{Declared Priority Sectors by NIPs}

There were 33 priority sectors in NIP 2005 and 32 in 2010 and there were no sub divisions in the priority, but in the NIP 2016 there was 7 high priority and 24 priority sectors. Though some sectors have been included in the priority and some are eliminated from the priority but priority sectors were almost consistent over the period. The researcher consider the NIP 2005 as the baseline for comparison in this study. By analyzing the priority sectors of this three NIPs the researcher observe the following shifting pattern:

Common in all the three NIPs: Agro-based industries (including agro-based food and equipment), RMG, Pharmaceutical, Home textile goods, Jute and jute goods, ICT and software industry, Leather and leather goods, Ceramics, Lite engineering, Electronics, Tourism, Handicrafts, Frozen fish, Cosmetics and toiletries, Tea industry, Furniture, Jewelry, Toy, Herbal medicine, Automobile making and repairing.

Industries newly included in the priority in 2010 and 2016: Plastic industry, Foreign employment, Shipbuilding industry, Environment friendly ship breaking industry, Active Pharmaceutical ingredient industry and Radio Pharmaceutical industry, Radioactive ray (radiation) application 
industry (for example, improve the quality of biodegradable polymer / preserve food grains/ medical equipment sterilization industry), Polymer production industry, Renewable power (solar power, windmill), Seed industry, Agor industry, Cement and producing energy efficient appliances.

Industries eliminated from the priority by NIP 2016: Artificial flower production, Integrated shrimp cultivation, Infrastructure, Oil and gas, Silkworm and silk industry, Basic chemicals/raw materials used in industries, Dye and chemicals used in textiles industry, Optical frame, Luggage fashion-based goods, CR coil, Stationery goods, Commercial plantation, Horticulture, Tissue grafting and biotechnology, Container Service, Warehouse, New innovation and import substitute industry.

\subsubsection{Priority Sectors Mentioned in the ITO 1984}

Under section 46A of ITO 1984: "industrial undertaking'" means an industry engaged in the production of textile, textile machinery, high value garments, pharmaceuticals, melamine, plastic products, ceramics, sanitary ware, steel from iron ore, fertilizer, insecticide $\&$ pesticide, computer hardware, petrochemical, basic raw materials of drugs, chemicals, pharmaceuticals, agricultural machine, ship building, boiler, compressors and other category of industrial undertaking as the govt. may by notification in the official gazette specify. (This definition is inserted by FA 2005.) U/s 46B: 'industrial undertaking' means an industry engaged in the production of - [This section is inserted by Finance Order (FO) 2008]:

(a) active pharmaceutical ingredient industry and radio pharmaceutical industry; aa) automobile manufacturing industry (inserted by FA 2015); (b) barrier contraceptive and rubber latex; (c) basic chemicals or dye and chemicals; (d) basic ingredients of electronic industry (e.g. resistance, capacitor, transistor, integrator circuit); (dd) bi-cycle manufacturing industry (inserted by FA 2015); (e) bio-fertilizer; (f) bio-technology; (g) boiler; (gg) brick made of automatic Hybrid Hofmann Kiln (inserted by FA 2015) or tunnel kiln technology (inserted by FA 2014); (h) compressors; (i) computer hardware; (j) energy efficient appliances; (k) insecticide or pesticide; (l) petro-chemicals; (m) pharmaceuticals; (n) processing of locally produced fruits and vegetables; (o) radio-active (diffusion) application industry (e.g. developing quality or decaying polymer or preservation of food or disinfecting medicinal equipment); (p) textile machinery; (q) tissue grafting; (qq) tyre manufacturing industry; (inserted by FA 2015); or (r) any other category of industrial undertaking as the govt. may by notification in the official gazette specify.

By observing the priority sectors mentioned in NIPs and in the definition of industrial undertaking in the ITO 1984, it was found that these sectors are almost similar by name. So this aspect of NIPs and tax incentives receiving industries are almost congruent. It also imply that coordination among ministry of industry and tax authority are satisfactory.

\subsection{Congruence in the Tax (direct) Incentives}




\subsubsection{Incentives suggested in NIPs}

NIP 2005 suggested some tax incentives like - tax holiday facilities based on the location of industries and condition for reinvestment. Accelerated depreciation were available for tax holiday availing and non-tax holiday availing units. As an alternative to tax holiday reduced rate for some sectors like RMG, jute goods production and textile industries were available.

NIP 2010 first categorized the incentives in three category as 1) tax holiday and depreciation, 2) incentives for NRBs and 3) other incentives. Emphasize on location based tax holiday facility. Tax holiday facility for private sector power generation companies for 15 years from the date of commercial production and continuation and expansion of some already given tax incentives.

In NIP 2016 there was recommendation for special incentives for the high priority sectors. Other tax incentives like tax holiday, accelerated depreciation and reduced rate were as same as mentioned in NIP 2010 under the provisions of ITO 1984.

\subsubsection{Incentives Actually Provided Under ITO 1984}

Tax holiday: There are a good number of tax holiday schemes available in Bangladesh under ITO 1984 for the industrial undertakings. It can categorized as: a) tax holiday under sections 45, 46, 46A, 46B and 46C and b) tax holiday under different S.R.O.s. Tax holiday period for some industries in the Special Economic Zone (SEZ), Hi-tech Parks are 10 to 12 years, private power generation companies (coal and non-coal based it is 10 to 15 years), industries in the EPZ (5 to 7 years), companies engaged in building physical infrastructure facilities [u/s 46C (2) for 10 years].

Accelerated depreciation: It is provided through the provisions of different paragraph of the third schedule of ITO 1984. It is also congruent with the NIPs suggested tax incentives. It is an incentive alternative to tax holiday.

Reduced Rate of Corporate tax: This tax incentive is applicable to certain industrial sectors like textile, jute and RMG etc. (under the provision of different S.R.O.s issued time to time by NBR). There are other types of tax incentives like exclusions/deductions from business income, tax rebate for CSR activities and double taxation relief under agreement between countries.

By analyzing the incentives suggested in the NIPs and incentives actually provided under ITO 1984, it can be said that almost all the tax incentives mentioned in the NIPs and incentives actually provided under ITO 1984 are almost same.

\section{Impact of Tax Incentives on Local Private Investment and GDP}

Tax incentives are generally used to attract local and foreign investment, nurture infant industries, and face regional tax competition and correct externalities (Barbour, 2005). Previous studies have shown that tax incentives can increase the FDI as well as local investment. Increased investment can expedite the industrial growth in many ways. In some recent studies mentioned in the literature review, have also shown that there is some spillover effect of FDI on local private sector 
development. In the following subsections the researcher has analyzed some economic data by line and bar charts to understand the impact of tax incentives on industrial development. Firstly the investment structure of Bangladesh has been shown to see the trend of local investment and FDI over total investment and then sectoral distribution of local investment are shown to see the growth and trend of manufacturing sector's investment and finally contribution of manufacturing sectors to GDP are presented to show the indirect and partial impact of tax incentives to the national development.

\subsection{Private Investment Scenario: Local, FDI and Total}

In Bangladesh investment structure comprises of local investment and foreign direct investment. Of them local investment is playing a vital role. Following graph has shown the investment structure of Bangladesh.

\section{INVESTMENT STRUCTURE OF BANGLADESH}

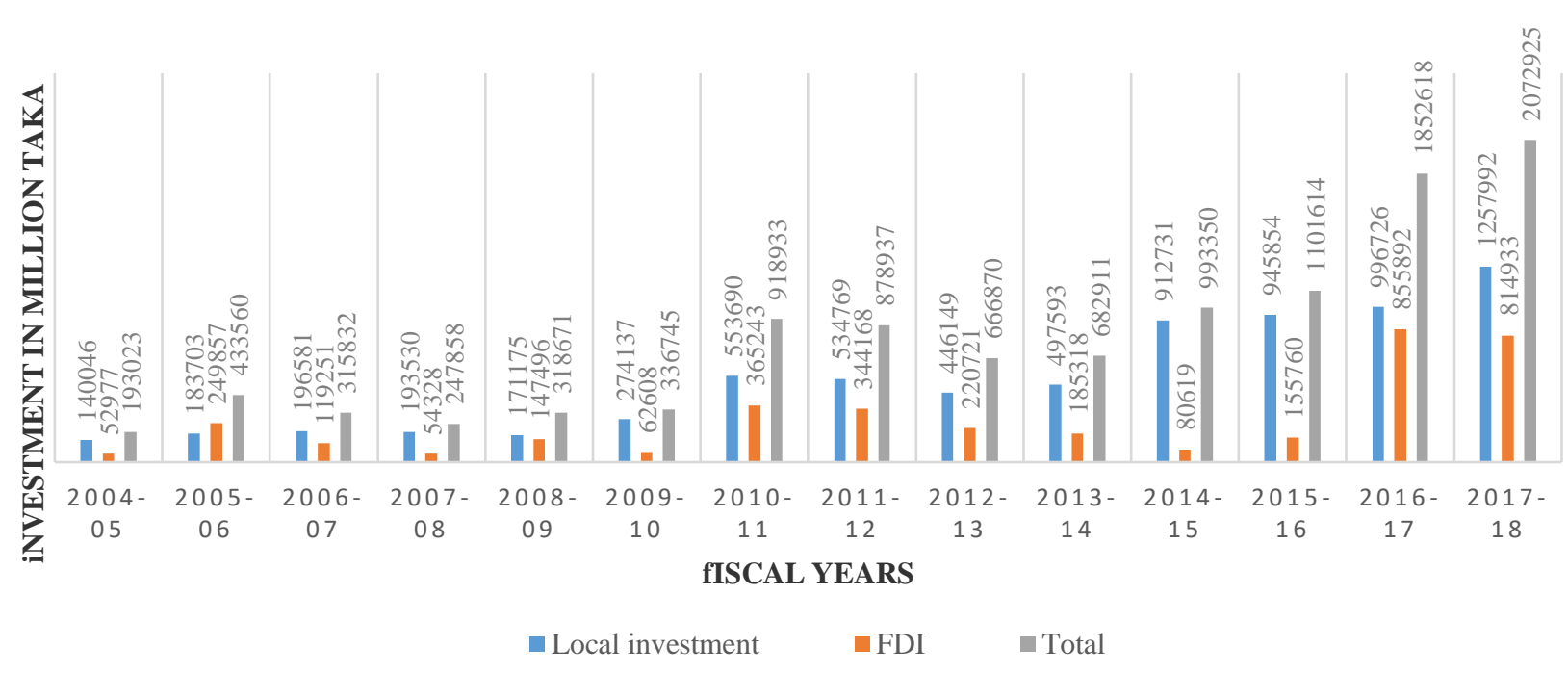

Source: Bangladesh Economic Review 2005-2018 and BIDA website

From the above chart we can comprehend the dominance of local investment over FDI. We also see the amount of investment was not so big up to 2009-10 fiscal year it was only 336 billion taka. But from 2010-11 fiscal year it was all most triple of previous year. Arithmetic average of local investment over total is 67.38 per year. In recent years it showed a very sharp increase in the total investment. It may be due to the liberalized incentive structure or peaceful political environment. Another reason of increase in investment are due to the implementation of NIP 2010 and 2016.

\subsection{Sectoral Distribution of Local Investments}

From the above graph it has known that local investment was the major contributor to the total investment. Now it need to know the sectoral distribution of those investments to know the trend of the most invested sectors. Following line chart has shown the sectoral distribution of local investments: 


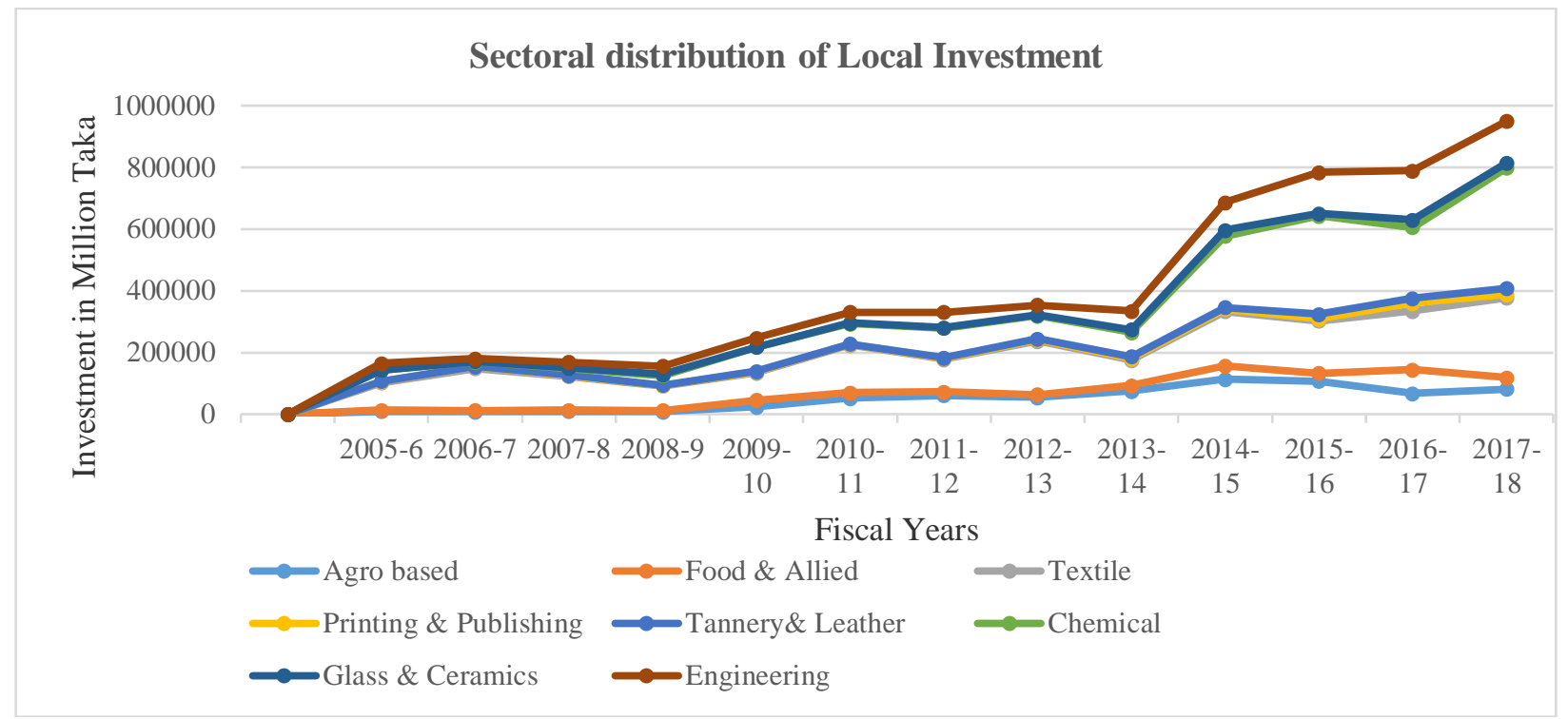

Source: Bangladesh Economic Review 2005-2018.

From the above line chart it is seen that there was consistent growth up to 2013-14 but from 14-15 there was a sharp increase in some sectors. The reason for these sharp increase might be due to the NIP 2010 and 2016 and the revised incentive structure of the tax authority. In some sectors like agro based and food and allied sectors have shown some negative growth due to the shifting priorities to the infrastructure, power and ICT. In this analysis two sectors has been excluded they are miscellaneous sector and service sector.

\subsection{Trend of the manufacturing Sectors Contribution to GDP}

In the previous chart sectoral distribution of the manufacturing sectors are presented to know the investment trend of those sectors. Now it is necessary to know the contribution of manufacturing sectors to the GDP of Bangladesh to fulfill the objective of this study.

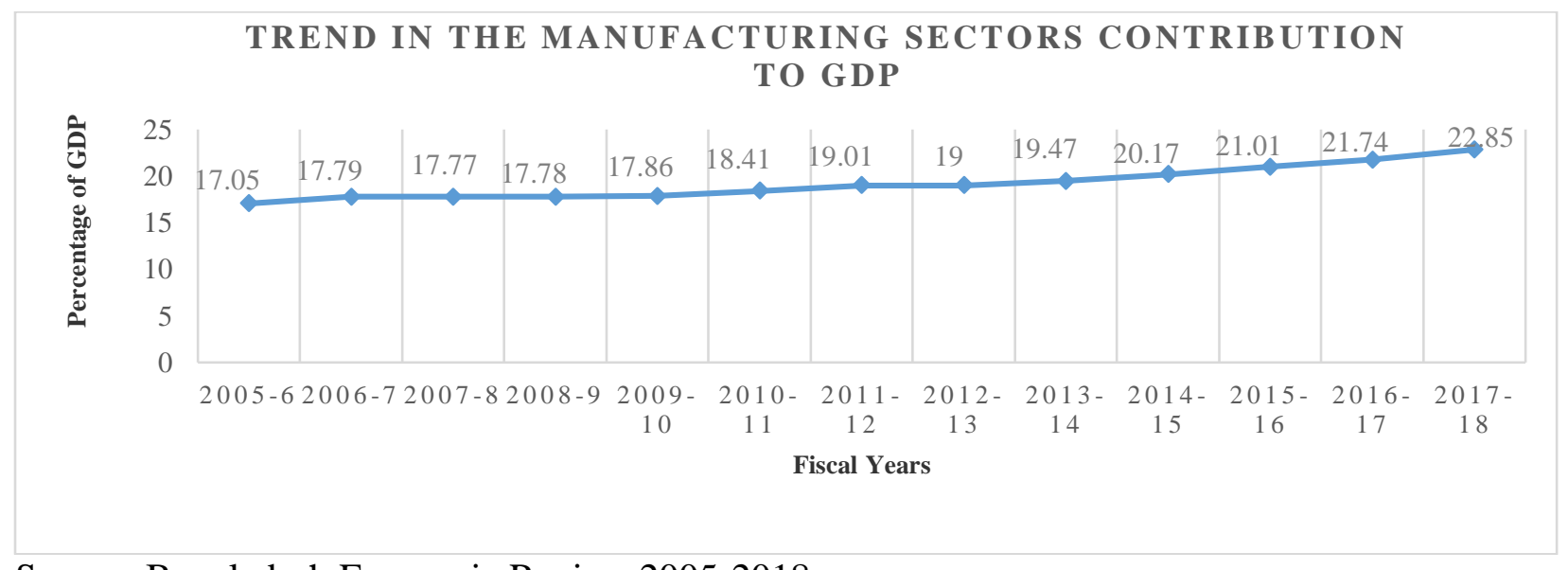

Source: Bangladesh Economic Review 2005-2018 
From the above line chart it has shown a consistent and increasing contribution of manufacturing sectors to the GDP. So there is a significant and steady contribution of manufacturing sectors to the development of Bangladesh.

\section{Conclusion}

Tax incentives and industrial polices review and the impact of these policies are described in this study. Priority sectors of the NIPs and incentives provided to the sectors under different sections of tax code and S.R.O.s were consistent over time. It was also visualized that in what manner priority has been changed over time in the NIPs and in the tax incentive structure of Bangladesh. There are different types of incentives like tax holiday, reduced tax rate, accelerated depreciation, tax rebate and tax relief under the provision of ITO 1984. Tax exemption period was vary from 5 to 15 years for investing in different location or in specific type of investment. Sectoral distribution of local investment projects (from 2005-18) has shown that there was consistency in the sectoral growth. Growth rate and contribution of the manufacturing sectors were steady over the period of time. Local private investment was dominant over FDI in both growth and actual amount invested. Scope of incentives have been increased over time and those incentives have attracted more investment. Those additional investments have contributed more to GDP. Thus the researcher can attribute additional GDP as the function of incentives provided by the tax authority. Some previous studies have also emphasized on non tax factor as equally important for increased investment and GDP. It is wise to say that not only the direct tax incentives but some other indirect tax incentives and non-tax factors are contributed to the increased local investment and gradual development of the industrial sectors in Bangladesh.

\section{References}

[1] Abdin, M. (2015). Foreign Direct Investment (FDI) in Bangladesh: Trends, Challenges and recommendation. International Journal of Economic and Management Science, 1-5.

[2] Alder, S., Shao, L., \& Zilibotti, F. (2013). Economic Reforms and Industrial Policy in a Panel of Chinese Cities. Zurich: UBS International Center of Economics in Society.

[3] Barbour, P. (2005). An assessment of South Africas investment incentives regime with a focus on the manufacturing sectors. London: Overseas Development Institute.

[4] Gebrewolde, T. M., \& Rockey, J. (2016). The effectiveness of Industrial Policy in Developing Countries: Causal evedence from Ethiopian Manufacturing Firms. Leicester: University of Leicester.

[5] Kee, H. L. (2015). Local intermediate inputs and the shared supplier spillovers of foreign direct investment. Journal of Development Economics, 56-71.

[6] Klemm, A., \& Parys, S. V. (2012). Empirical evidence on the effects of tax incentives. Int Tax Public Finance, 393-423.

[7] Konings, J. (2001). The effects of foreign direct investment of domestc firms . Economics of Transition, 619-633.

[8] Munongo, S., Akanbi, O. A., \& Robinson, Z. (2017). Do tax incentives matter for investment? A literature review. Business and Economic Horizons, 152-168.

[9] OECD. (2007). Tax incentives for Investment- A global Perspective: Experiences in MENA and Non-MENA countries. OECD.

[10] Oriakhi, D. E., \& Osemwengie, P. K. (2013). Tax Incentives and Revenue Productivity of the Nigerian tax systems. International Journal of Development and Economic Sustainability, 31-44. 
[11] Robin, I. A. (2006). Foreign Direct Investment: Impact on sectoral growth in Bangladesh. Dhaka: Bangladesh.

[12] Siyanbola, T. T., Adedeji, S. B., Festus, F., \& Rahman, M. M. (2017). Tax incentives and industrial/economic growth of sub-Saharan African States . Journal of Advanced Research in Business and Management Studies, 78-90.

[13] The institute of fiscal studies. (2018). Are corporate tax incentives for investment fit for purpose? Revisiting economic principles and evidence from low and middle income countries. London: The institute of fiscal studies.

*Corresponding author.

E-mail address: munayem.du@ gmail.com 